\title{
Paleoenvironmental Evolution of Continental Carbonates in West-Central Brazil
}

\author{
EMILIANO C. OLIVEIRA ${ }^{1}$, DILCE F. ROSSETTI ${ }^{2}$ and GISELLE UTIDA ${ }^{3}$ \\ ${ }^{1}$ Departmento de Ciências do Mar, Instituto de Saúde e Sociedade, Universidade Federal de São \\ Paulo, Rua Doutor Carvalho de Mendonça, 144, 11070-100 Santos, SP, Brazil \\ ${ }^{2}$ Divisão de Sensoriamento Remoto, Instituto Nacional de Pesquisa Espacial, Avenida \\ dos Astronautas, 1758, 12227-010 São José dos Campos, SP, Brazil \\ ${ }^{3}$ Programa de Pós-Graduação em Geoquímica e Geotectônica, Instituto de Geociências, \\ Universidade de São Paulo, Rua do Lago, 522, 05508-080 São Paulo, SP, Brazil
}

Manuscript received on September 1, 2016; accepted for publication on November 11, 2016

\begin{abstract}
This paper presents a sedimentological and stratigraphical study of Quaternary (Middle to Late Pleistocene/ Holocene) continental carbonates outcrops inside Pantanal Basin and its surroundings, especially in Serra da Bodoquena, Pantanal do Miranda and Corumbá/Ladário plateau, in the state of Mato Grosso do Sul, as well as in Serra das Araras, in the state of Mato Grosso. The aim is to understand the depositional paleoenvironments and analyse climate and tectonic influences in their genesis and evolution. The results show that the deposition of these continental carbonates started in the Middle to Late Pleistocene and have continued, with some interruptions, until the present days. Sedimentary successions were identified in the different areas, without complete correlation. Two sedimentary successions separated by an erosional surface were described in Serra da Bodoquena and Serra das Araras. In Corumbá and Pantanal do Miranda, only one succession was described. These successions were deposited in elongated lakes parallel to fault planes; small lakes, related plains and plateaus; springs related to cliffs produced by faulting; rivers conditioned by topographic variation. The climatic interpretation, without proper temporal resolution, obtained by the stable-isotope composition and stratigraphic interpretation, indicates alternation of dry and wet periods. The Neoproterozoic faults with their neotectonics and the subsidence of the Pantanal Basin, are the major control for carbonated water flow and development of depositional areas, gradually turning plateaus into slight tilted areas, allowing the evolution of depositional systems from lakes to rivers.
\end{abstract}

Key words: central Brazil, continental carbonates, Holocene, paleoenvironments, Pantanal Basin, Pleistocene.

\section{INTRODUCTION}

Continental carbonates have particular sedimentological, geomorphological and chemical characteristics and commonly form a significant

Correspondence to: Emiliano Castro de Oliveira

E-mail: emiliano.oliveira@unifesp.br

* Contribution to the centenary of the Brazilian Academy of Sciences. component of the continental successions (AlonsoZarza and Tanner 2010). The use of continental carbonates for local and global paleoclimate analysis is common in many environments, including tropical ones (Carthew et al. 2003, 2006), where it is possible to correlate their types to regional climatic history, tectonic setting and carbonated water sources. However, field 
interpretation of tropical carbonate facies and their paleoenvironments can be difficult, especially where weathering, pedogenesis or shallow burial have erased the main geomorphic, stratigraphic and textural details. In particular, subaerial exposure and pedogenesis can result in extensive modification to the form, texture and composition of the original deposit (Alonso-Zarza 2003, Wright and Tucker 1991). Field interpretations can be enhanced significantly if local tectonic and climatic factors are well understood, as these control the types and nature of the deposits and their paleoenvironments.

There are many studies of the paleoenvironmental evolution of Quaternary continental carbonates in temperate and semi-arid settings, describing tufas, lacustrine, palustrine, travertines and calcrete facies in active and inactive tectonic settings (e.g. Alonso-Zarza et al. 2012, Arenas et al. 2014, Capezzuoli et al. 2014). However, there are few studies of continental carbonates in Brazil despite significant occurrences in the Pantanal Basin and its surroundings, in westcentral Brazil (Boggiani et al. 1999, Boggiani and Coimbra 1995, Corrêa et al. 2011, Sallun Filho et al. 2009a), in the northern part of the state of Bahia (Auler and Smart 2001, Wang et al. 2004), in São Paulo state (Almeida et al. 2011, Basilici et al. 2009, Fernandes and Basilici 2009) and in the state of Rio Grande do Sul (Horn et al. 2013).

Although studies in temperate and semiarid settings have produced models to interpret the evolution of continental carbonates, the development of specific models for this type of tropical setting, as presented by Carthew et al. (2003), which includes the influence of tectonic activity, is essential to correctly interpret continental carbonate sequences. Continental carbonate deposits developed in the Pantanal Basin and its surroundings, particularly in the Serra da Bodoquena, Pantanal do Miranda and Corumbá/ Ladário plateau, in the state of Mato Grosso do Sul, as well as in the Serra das Araras, in the state of Mato Grosso. The Pleistocene, Holocene and contemporary deposits provide a scenario where the paleoenvironmental characteristics of a tropical setting can be studied and compared to similar researches on temperate and semi-arid settings.

Thus, the aims of this paper are (i) to describe the depositional paleoenvironments of the continental carbonates in the Pantanal Basin vicinity and (ii) to analyse the influence of climate and tectonics in their genesis during the Quaternary.

\section{REGIONAL SETTING}

The region studied in this article is located in westcentral Brazil, and includes the southwest part of the Pantanal Basin and the Paraguay Fold Belt (Fig. 1). The relief is characterized by a depression, the Pantanal Basin, surrounded by plateaus and ranges (serras). The basement rocks and sediments for the Quaternary continental carbonates of the area comprises low-grade metamorphic rocks, including limestone, dolomite and claystone (Corumbá and Araras Groups) from the Neoproterozoic, in the Paraguay Fold Belt (Boggiani and Alvarenga 2004, Teixeira et al. 1989) and siliciclastic sediments, mostly quartz sand and clay, in the Pantanal Basin (Assine et al. 2015, Assine and Soares 2004). The continental carbonate occurrences are related to present-day and former springs, fluvial and palustrine and lacustrine systems in the plateaus and ranges, with the formation of carbonate-rich water in these systems related to weathering and dissolution of the host rock around the Pantanal Basin, and clast within the oldest lobe of the Taquarí Megafan, the biggest sedimentary structure of the basin, formed by Taquarí river sediments and avultion process (Assine et al. 2015, Assine and Soares 2004).

In the Serra das Araras, basement outcrops can reach $800 \mathrm{~m}$ above sea level, where they form cliffs resulting from NE-SW folds, faults and lineaments (Fig. 1a). Gaps of approximately 


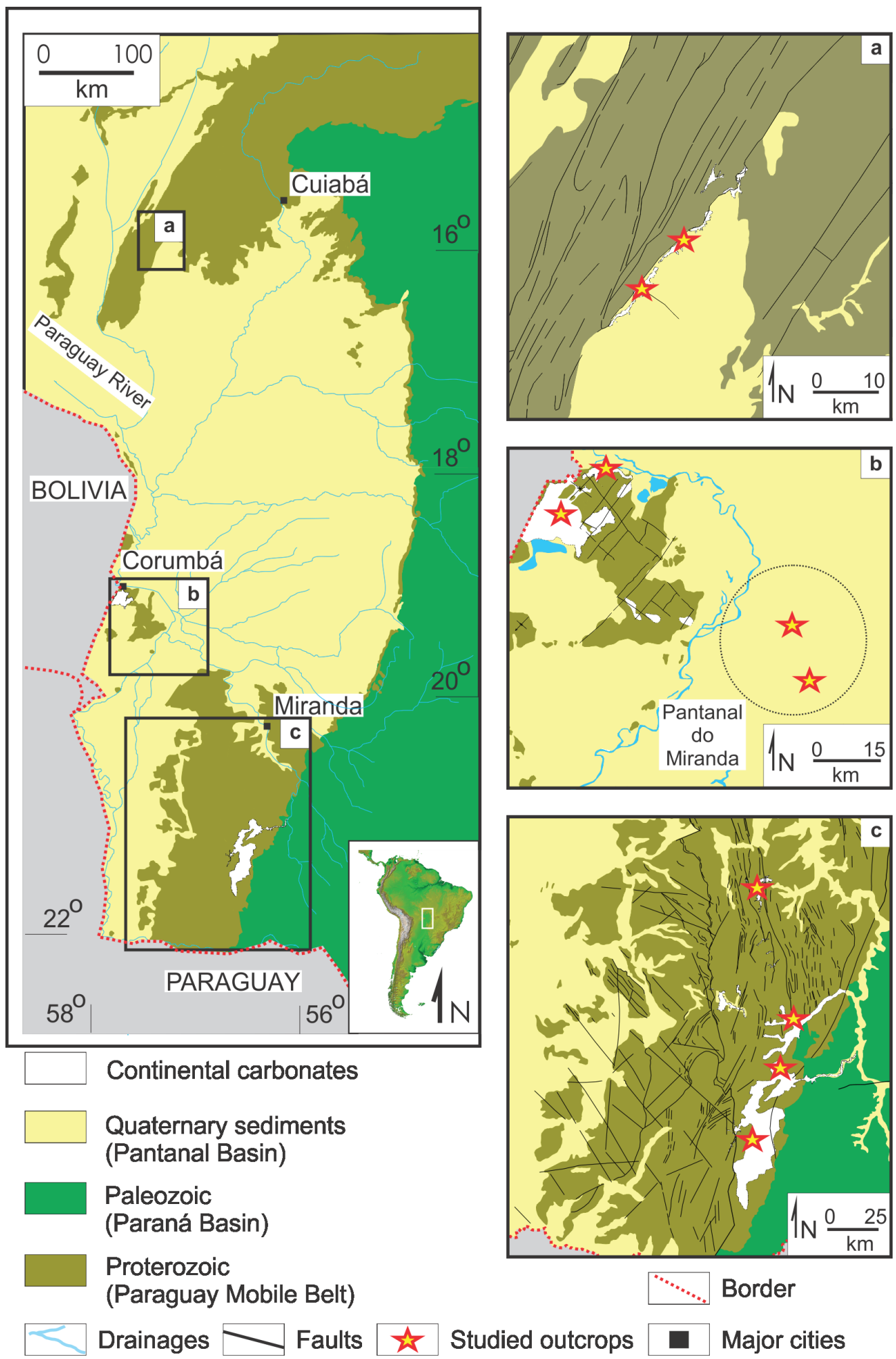

Figure 1 - Simplified geological map of Paraguay's Mobile Belt indicating location of studied areas: a: Serra das Araras; b: Corumbá/Ladário plateau and Pantanal do Miranda; c: Serra da Bodoquena (modified from Lacerda Filho et al. 2004a, b, Valente et al. 2004). 
$300 \mathrm{~m}$ have been recorded on a narrow plateau composed of Quaternary deposits of the Xaraiés Formation (Corrêa et al. 2011) and siliciclastic debris, which is $300 \mathrm{~m}$ above sea level. In this context, the occurrence of continental carbonates is associated with the scarp of the range, and four narrow elongated bodies are developed along faults which puts them in lateral contact with basement rocks (Fig. 1a). The Corumbá/Ladário plateau, with average altitude of $120 \mathrm{~m}$, is characterized by a relatively flat area, associated with high mountains formed by NE-SW and NW-SE normal faults (Fig. 1b). It consists of basement rocks which are overlain by continental carbonates (Almeida 1945, Boggiani and Coimbra 1995). In the Serra da Bodoquena, a mountain range of Neoproterozoic strata reaching $600 \mathrm{~m}$ above sea level, controlled by NNW-SSE normal faults in the north and NW-SE, NE-SW and NS directions in its south-central portion, there are remarkable occurrences of continental carbonates. Finally, in the Pantanal do Miranda located in the Pantanal Basin, with an altitude of approximately $90 \mathrm{~m}$, lenses of continental carbonates occur directly on the oldest lobe (Pleistocene) of the Taquarí river megafan (Assine and Soares 2004).

The origin of Pantanal Basin, averaging $135,000 \mathrm{~km}^{2}$ with altitudes between $80 \mathrm{~m}$ and $200 \mathrm{~m}$, is related to the Early Quaternary tectonic reactivation, which occurred during the last Andean compressive event (Ussami et al. 1999). It's filling was controlled by alluvial, fluvial and lacustrine sedimentary systems, with the Taquarí river megafan covering more than $37 \%$ of the basin area (Assine et al. 2015, Assine and Soares 2004). The ranges and plateaus are characterized by outcrops of basement limestones and dolostones associated with fluvial plains (Almeida 1945, Boggiani et al. 1999, Corrêa et al. 2011).

The climate in the region is tropical monsoonal (Alvares et al. 2013, Soto et al. 2006), strongly influenced by the South American Summer Monsoon (SASM) and by the South American
Converge Zone (SACZ) (Rao et al. 1996). Winter temperatures are around $22^{\circ} \mathrm{C}$, and summer temperatures are around $27.5^{\circ} \mathrm{C}$, with significant contrast in seasonal rainfall, with $900 \mathrm{~mm}$ during the summer months and around $100 \mathrm{~mm}$ during the winter (Gan et al. 2004). Temperature is influenced by continentality and relief, with high temperatures in the low lands and low temperatures in the high lands. During the winter, some Antarctic air masses raise humidity some days with intense temperature cooling $\left(30^{\circ} \mathrm{C}\right.$ in less than 12 hours) (Marengo et al. 2012, Vera et al. 2006).

Climate reconstructions for south-eastern Brazil, during the Late Pleistocene, suggest periods of higher water abundance, related to the intensification of South American summer monsoon (Cruz et al. 2005). This climatic context persisted throughout the Holocene, with an incidence of more frequent and more abrupt events, such as BOND Events in the North Atlantic and solar forcing, which have been recorded in central Brazil deposits (Bertaux et al. 2002, Strikis et al. 2011, Vuille et al. 2012, Novello et al. 2016).

Some studies in this area (Boggiani et al. 1999, 1998, Corrêa et al. 2011, Ribeiro et al. 2015, Sallun Filho et al. 2009b, Turcq et al. 1987, This study) were successful in dating the continental carbonates, providing 37 ages, ranging from more than 600.000 years before present (600 kyr $\mathrm{BP})$ to $0.65 \mathrm{kyr} \mathrm{BP}$ (Table I), suggesting that the deposition of carbonates was not continuous. Serra das Araras presents the oldest stages of deposition, in the Middle Pleistocene (probably 2 stages) and ending in the Late Pleistocene (probably 1 stage): 525 to $440 \mathrm{kyr}$ BP, 288 to $223 \mathrm{kyr} \mathrm{BP}, 111$ to $75 \mathrm{kyr}$ BP. Deposits on the Corumbá plateau also have a Middle Pleistocene age: 312 kyr BP. Pantanal do Miranda carbonates represent only one Holocene stage; 3.9 kyr BP. Occurrences in the Serra da Bodoquena give intermediate to modern ages, with Late Pleistocene (2 stages) and Holocene, 
continuing to the present day (1 stage): $118 \mathrm{kyr} \mathrm{BP,}$ 75 to $51 \mathrm{kyr}$ BP, $5.8 \mathrm{kyr}$ BP to $0.65 \mathrm{kyr}$ BP.

In the Serra das Araras two facies of continental carbonates were recognized (Almeida 1954, Corrêa et al. 2011): directly overlying the basement limestones there is a basal layer of conglomerates, described as pinkish micritic calcite conglomerate with quartz and limestone pebbles, and local occurrence of gastropods; a top layer of tufas directly overlying the basal conglomerate, described as tufas related with springs, cascades, pendants and perched springline types, rich in detrital components as well as in plant and gastropods remains. On the Corumbá/Ladário plateau two facies were recognized (Almeida 1945, Boggiani and Coimbra 1995): directly overlying the carbonate-rich basement; there is a basal layer of conglomerates, 0.5 to $9 \mathrm{~m}$ thick, described as polymictic conglomerate with a micritic matrix, and a layer of brecciated wackestone, 0.5 to $1 \mathrm{~m}$ thick, described as limestone rich in plant and shells remains. In the Pantanal do Miranda area only one facies of continental carbonates has been recognized (Boggiani and Coimbra 1995): directly overlying quartz sands of the Pantanal Formation (Assine and Soares 2004), some lenses, 100 to $300 \mathrm{~m}^{2}$ and 1 to $1.5 \mathrm{~m}$ thick, of quartz sand rich wackestone, described as sub-rounded fine-grained quartz sand supported by fine calcite matrix, rich in gastropod shells. In the Serra da Bodoquena two facies were recognized (Almeida 1965, Boggiani et al. 1999, Sallun Filho et al. 2009a): overlying the carbonate basement there is a basal layer of fossiliferous wackestone, described as micritic sediment, rich in fossil gastropods; a top layer of tufas (barrage, stromatolite, cascade types), directly overlying the basal wackestone. The stratigraphy of the continental carbonates of the Pantanal Basin and its surroundings can be seen in Figure 2.

In the first studies (Almeida 1945, 1954) all continental carbonates of the Pantanal Basin and its surroundings were considered as one unique geological unit, the Xaraiés Formation, despite the distances and stratigraphic characteristics between the occurrences (Fig. 1). More recently, Sallun Filho et al. (2009a) proposed the term Serra da Bodoquena Formation to describe the Upper Pleistocene and Holocene deposits of this area, related to lacustrine and fluvial settings. In the Serra das Araras, Corrêa et al. (2011) used Xaraiés Formation to name the Middle to Upper Pleistocene spring, fluvial and lacustrine deposits.

\section{MATERIALS AND METHODS}

The field and laboratory analysis of the stratigraphy and sedimentology of the continental carbonates combined with the available dates for the main outcrops led to the assessment of the time of deposition of the various continental carbonates. Four stratigraphic sections were measured in each studied area.

The cartographic representation of the continental carbonate occurrences was produced by associating field data, existing maps and images from the Shuttle Radar Topography Mission (S 15 to 23; W 54 to 60; version 3 - SRTM3). The SRTM data were combined into a Digital Elevation Model (DEM) and then associated with the field data, using $52^{\circ}$ north ILWIS 3.8 free software. Maps from other authors (Boggiani and Coimbra 1995, Corrêa et al. 2011, Sallun Filho and Karmann 2007) were digitalized and combined with the DEM images to generate an initial continental carbonate map. All the maps were finished in Inkscape free software.

Several tens of samples of the different carbonate facies were collected for analysis of their sedimentological features and to support field descriptions and interpretations. A set of 58 samples was subjected to conventional optical petrographic analysis on a Zeiss AXIOPLAN 2 microscopy. In view of the fragility of some samples, these were previously submerged in a resin containing Epofer EX 401 and Epofer E 432 in a vacuum system. 


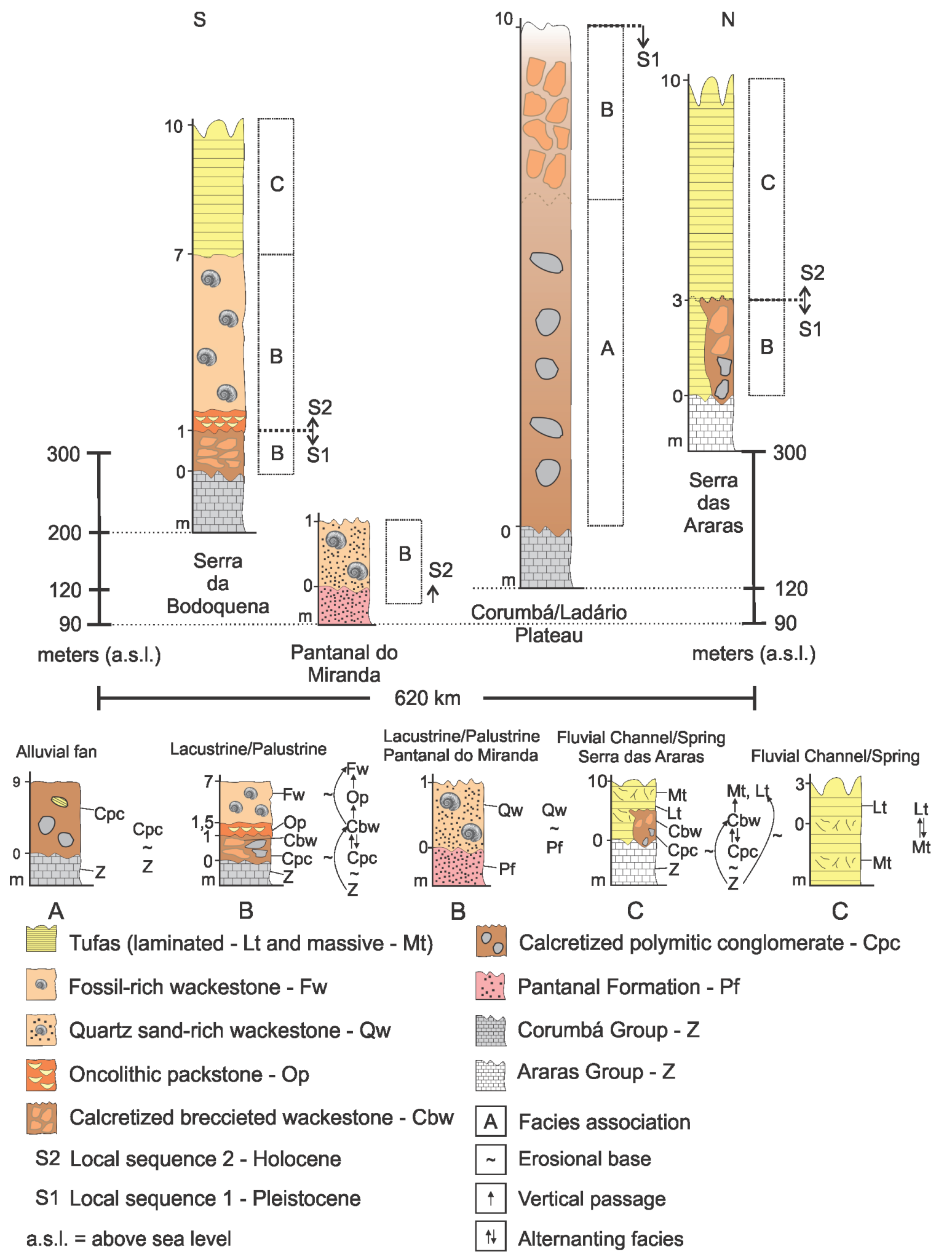

Figure 2 - Composite stratigraphic sections of the studied areas, with facies association representative of the different environments present in the studied area, without stratigraphic correlation. 
Characteristics such as mineralogy, textures, siliciclastic components, structures, matrix type and paleontology were analysed to interpret their genesis. The classification scheme of Dunham (1962), modified by Embry and Klovan (1971) and Wright (1992), and applied by Della Porta (2015) to classify continental carbonates, based on texture, was applied to name the sedimentary facies.

A set of 66 samples was selected for bulk sample analyses of carbon and oxygen stable isotopes. Extraction was made with a microdrill. Isotopic determinations were carried out on a DeltaPLUS Advantage mass spectrometer at the Stable Isotope Analysis Laboratory of the Geosciences Institute of the University of São Paulo (Brazil). All the analytical processes followed the standard methods (McCrea 1950), and the analytical precision and replica analyses were better than $0.05 \%$ for carbon and $0.07 \%$ for oxygen. The results are expressed in $\delta \%$ units and reported against the Vienna Pee Dee Belemnite (VPDB) standard (Table II).

As a result of the impure nature of the carbonate samples, with high concentrations of initial ${ }^{230} \mathrm{Th}$, only one sample, a conglomerate from the Corumbá/Ladário plateau, was dated by the U-series method, at the Geochronology Laboratory of the Geology Department of the University of Minnesota (USA), applying a Thermo Finnigan Element I magnet-sector inductively coupled plasma mass spectrometer (ICP-MS), according to standard chemical and analytical methods (Shen et al. 2002). This dated sample yields an error $(2 \sigma)$ $<1 \%$.

\section{RESULTS}

\section{STRATIGRAPHY}

The continental carbonates described in this study were deposited directly upon the carbonate basement, with an angular unconformity which also represents an erosional surface, in Serra das Araras, Corumbá/Ladário plateau and Serra da
Bodoquena and, in Pantanal do Miranda, with an abrupt contact over Pleistocene sediments of the Pantanal Formation (Fig. 2). The sections range from $1 \mathrm{~m}$ in Pantanal do Miranda, to almost 9 $\mathrm{m}$ on the Corumbá/Ladário plateau, and consist of lacustrine (wackestone) and fluvial (tufa) carbonates deposited over debris flow carbonate sediments (conglomerate) and/or brecciated lacustrine (wackestone and packestone) carbonates in all studied areas, except in Pantanal do Miranda, where the lacustrine (wackestone) carbonates lie over quartz sands of Pantanal Formation. Thus, it is possible to identify 2 sedimentary successions that are physically and stratigraphically disconnected. The chronology presented here (Table I) uses data from many regional papers (Boggiani et al. 1998, Boggiani et al.1999, Corrêa et al. 2011, Ribeiro et al. 2015, Sallun Filho et al. 2009a, Turcq et al. 1987).

\section{PLEISTOCENE DEPOSITS}

The Serra das Araras occurrence is composed only of Pleistocene carbonates, with conglomerate and wackestone in the lower part of the sequence and tufas, which in some places are related to the basement and elsewhere crop out above the conglomerate or wackestone (Fig. 2). The relations between the different carbonates are always associated with erosional surfaces. The tufas are generally associated with the scarps of the Serra das Araras, forming numerous elongated bodies along the main fault. The chronological data (Table I) indicate several stages of tufa deposition: 525 to 520 kyr BP; 490 to 440 kyr BP; 312 kyr BP; 285 kyr BP; 228 to $223 \mathrm{kyr}$ BP; 111 to $102 \mathrm{kyr} \mathrm{BP} ; 75$ kyr BP, and the conglomerates and wackestones are older than 600 kyr BP (Corrêa et al. 2011). On the Corumbá/Ladário plateau, the succession is composed only of Pleistocene carbonates with conglomerates occurring directly on the basement, pass up into wackestones (Fig. 2). These sediments 
TABLE I

Compiled ages of Quaternary continental carbonates of Serra da Bodoquena, Corumbá plateau, Serra das Araras and Pantanal do Miranda. Symbols: Rock Type: $\mathrm{Tf}=$ Tufa; $\mathbf{W c}=$ Wackestone; $\mathrm{Cl}=$ Conglomerate; Area: $\mathrm{SB}=\mathrm{Serra}$ da Bodoquena; Pantanal do Miranda = PM; SA = Serra das Araras; CO = Corumbá/Ladário Plateau.

\begin{tabular}{|c|c|c|c|c|c|c|c|c|c|}
\hline $\begin{array}{c}\text { Ages } \\
\text { (kyr BP) }\end{array}$ & $\begin{array}{c}\text { Rock } \\
\text { type }\end{array}$ & Area & Method & Author & $\begin{array}{c}\text { Ages } \\
\text { (kyr BP) }\end{array}$ & $\begin{array}{c}\text { Rock } \\
\text { type }\end{array}$ & Area & Method & Author \\
\hline $0.65 \pm 0.04$ & $\mathrm{Tf}$ & SB & ${ }^{14} \mathrm{C}$ & $\begin{array}{l}\text { Sallun Filho } \\
\text { et al. } 2009 \mathrm{~b}\end{array}$ & $102 \pm 10$ & $\mathrm{Tf}$ & SA & $\mathrm{U} / \mathrm{Th}$ & $\begin{array}{c}\text { Corrêa et al. } \\
2011\end{array}$ \\
\hline $0.80 \pm 0.1$ & $\mathrm{Tf}$ & SB & OSL & $\begin{array}{c}\text { Ribeiro et al. } \\
2015\end{array}$ & $111 \pm 5$ & $\mathrm{Tf}$ & SA & $\mathrm{U} / \mathrm{Th}$ & $\begin{array}{c}\text { Corrêa et al. } \\
2011\end{array}$ \\
\hline $2.13 \pm 0.06$ & $\mathrm{Tf}$ & SB & ${ }^{14} \mathrm{C}$ & $\begin{array}{c}\text { Boggiani et } \\
\text { al. } 1999\end{array}$ & $118.6 \pm 10$ & $\mathrm{Tf}$ & SB & OSL & $\begin{array}{c}\text { Ribeiro et al. } \\
2015\end{array}$ \\
\hline $2.15 \pm 0.5$ & Wc & SB & ${ }^{14} \mathrm{C}$ & $\begin{array}{c}\text { Turcq et al. } \\
1987\end{array}$ & $223 \pm 8$ & $\mathrm{Tf}$ & SA & $\mathrm{U} / \mathrm{Th}$ & $\begin{array}{c}\text { Corrêa et al. } \\
2011\end{array}$ \\
\hline $2.42 \pm 0.7$ & $\mathrm{Tf}$ & SB & ${ }^{14} \mathrm{C}$ & $\begin{array}{c}\text { Boggiani et } \\
\text { al. } 1999\end{array}$ & $223 \pm 8$ & $\mathrm{Tf}$ & SA & $\mathrm{U} / \mathrm{Th}$ & $\begin{array}{c}\text { Corrêa et al. } \\
2011\end{array}$ \\
\hline $2.63 \pm 0.06$ & $\mathrm{Wc}$ & SB & ${ }^{14} \mathrm{C}$ & $\begin{array}{l}\text { Sallun Filho } \\
\text { et al. } 2009 \mathrm{~b}\end{array}$ & $227 \pm 7$ & $\mathrm{Tf}$ & SA & $\mathrm{U} / \mathrm{Th}$ & $\begin{array}{c}\text { Corrêa et al. } \\
2011\end{array}$ \\
\hline $3.41 \pm 0.07$ & $\mathrm{Tf}$ & SB & ${ }^{14} \mathrm{C}$ & $\begin{array}{c}\text { Boggiani et } \\
\text { al. } 1999\end{array}$ & $228 \pm 7$ & $\mathrm{Tf}$ & SA & $\mathrm{U} / \mathrm{Th}$ & $\begin{array}{c}\text { Corrêa et al. } \\
2011\end{array}$ \\
\hline $3.91 \pm 0.11$ & $\mathrm{Wc}$ & PM & ${ }^{14} \mathrm{C}$ & $\begin{array}{c}\text { Boggiani et } \\
\text { al. } 1998\end{array}$ & $285 \pm 10$ & $\mathrm{Tf}$ & SA & $\mathrm{U} / \mathrm{Th}$ & $\begin{array}{c}\text { Corrêa et al. } \\
2011\end{array}$ \\
\hline $4.20 \pm 0.04$ & Wc & SB & ${ }^{14} \mathrm{C}$ & $\begin{array}{l}\text { Sallun Filho } \\
\text { et al. } 2009 \mathrm{~b}\end{array}$ & $288 \pm 10$ & $\mathrm{Tf}$ & SA & $\mathrm{U} / \mathrm{Th}$ & $\begin{array}{c}\text { Corrêa et al. } \\
2011\end{array}$ \\
\hline $4.20 \pm 0.7$ & $\mathrm{Tf}$ & SB & OSL & $\begin{array}{c}\text { Ribeiro et al. } \\
2015\end{array}$ & $302 \pm 57$ & $\mathrm{Cl}$ & $\mathrm{CO}$ & $\mathrm{U} / \mathrm{Th}$ & This study \\
\hline $5.20 \pm 0.24$ & $\mathrm{Wc}$ & SB & ${ }^{14} \mathrm{C}$ & $\begin{array}{c}\text { Turcq et al. } \\
1987\end{array}$ & $312 \pm 19$ & $\mathrm{Tf}$ & SA & $\mathrm{U} / \mathrm{Th}$ & $\begin{array}{c}\text { Corrêa et al. } \\
2011\end{array}$ \\
\hline $5.50 \pm 0.4$ & $\mathrm{Tf}$ & SB & OSL & $\begin{array}{c}\text { Ribeiro et al. } \\
2015\end{array}$ & $440 \pm 60$ & $\mathrm{Tf}$ & SA & $\mathrm{U} / \mathrm{Th}$ & $\begin{array}{c}\text { Corrêa et al. } \\
2011\end{array}$ \\
\hline $5.65 \pm 0.05$ & $\mathrm{Wc}$ & SB & ${ }^{14} \mathrm{C}$ & $\begin{array}{l}\text { Sallun Filho } \\
\text { et al. 2009b }\end{array}$ & $470 \pm 30$ & $\mathrm{Tf}$ & SA & $\mathrm{U} / \mathrm{Th}$ & $\begin{array}{c}\text { Corrêa et al. } \\
2011\end{array}$ \\
\hline $51.9 \pm 4.8$ & $\mathrm{Tf}$ & SB & OSL & $\begin{array}{c}\text { Ribeiro et al. } \\
2015\end{array}$ & $490 \pm 30$ & $\mathrm{Tf}$ & SA & $\mathrm{U} / \mathrm{Th}$ & $\begin{array}{c}\text { Corrêa et al. } \\
2011\end{array}$ \\
\hline $55.8 \pm 13.7$ & $\mathrm{Tf}$ & SB & OSL & $\begin{array}{c}\text { Ribeiro et al. } \\
2015\end{array}$ & $520 \pm 40$ & $\mathrm{Tf}$ & SA & $\mathrm{U} / \mathrm{Th}$ & $\begin{array}{c}\text { Corrêa et al. } \\
2011\end{array}$ \\
\hline $75.0 \pm 14.0$ & $\mathrm{Tf}$ & SB & OSL & $\begin{array}{c}\text { Ribeiro et al. } \\
2015\end{array}$ & $525 \pm 50$ & $\mathrm{Tf}$ & SA & $\mathrm{U} / \mathrm{Th}$ & $\begin{array}{c}\text { Corrêa et al. } \\
2011\end{array}$ \\
\hline $75.2 \pm 0.9$ & $\mathrm{Tf}$ & SA & $\mathrm{U} / \mathrm{Th}$ & $\begin{array}{c}\text { Corrêa et al. } \\
2011\end{array}$ & $>600$ & $\mathrm{Cl}$ & SA & $\mathrm{U} / \mathrm{Th}$ & $\begin{array}{c}\text { Corrêa et al. } \\
2011\end{array}$ \\
\hline $75.2 \pm 1.2$ & $\mathrm{Tf}$ & SA & $\mathrm{U} / \mathrm{Th}$ & $\begin{array}{c}\text { Corrêa et al. } \\
2011\end{array}$ & $>600$ & $\mathrm{Cl}$ & SA & $\mathrm{U} / \mathrm{Th}$ & $\begin{array}{c}\text { Corrêa et al. } \\
2011\end{array}$ \\
\hline
\end{tabular}


TABLE II

$\delta^{13} \mathrm{C}$ and $\delta^{18} \mathrm{O}$ compositions for different facies associations of Quaternary continental carbonates of Serra da Bodoquena, Corumbá plateau, Serra das Araras and Pantanal do Miranda.

\begin{tabular}{|c|c|c|c|c|c|c|c|c|}
\hline $\begin{array}{l}\text { Facies } \\
\text { Assoc. }\end{array}$ & $\begin{array}{c}\delta^{13} \mathrm{C} \\
\left(\%{ }^{2} \mathrm{PDB}\right) \\
\end{array}$ & $\begin{array}{c}\delta^{18} \mathrm{O} \\
(\% \mathrm{PDB})\end{array}$ & $\begin{array}{l}\text { Facies } \\
\text { Assoc. }\end{array}$ & $\begin{array}{c}\delta^{13} \mathrm{C} \\
\left(\%{ }^{\circ} \mathrm{PDB}\right)\end{array}$ & $\begin{array}{c}\delta^{18} \mathrm{O} \\
\left(\%{ }^{\circ} \mathrm{PDB}\right)\end{array}$ & $\begin{array}{l}\text { Facies } \\
\text { Assoc. }\end{array}$ & $\begin{array}{c}\delta^{13} \mathrm{C} \\
\left(\%{ }^{2} \mathrm{PDB}\right)\end{array}$ & $\begin{array}{c}\delta^{18} \mathrm{O} \\
(\% \mathrm{PDB})\end{array}$ \\
\hline A & -7.13 & -6.97 & B & -6.67 & -6.64 & $\mathrm{C}$ & -2.80 & -8.87 \\
\hline A & -6.89 & -6.48 & B & -7.08 & -5.33 & $\mathrm{C}$ & -2.66 & -8.40 \\
\hline A & -6.70 & -7.72 & B & -7.05 & -4.21 & $\mathrm{C}$ & -4.88 & -7.09 \\
\hline A & -7.70 & -7.15 & B & -5.93 & -6.84 & $\mathrm{C}$ & -4.71 & -6.65 \\
\hline A & -7.31 & -7.64 & B & -7.03 & -5.43 & $\mathrm{C}$ & -5.10 & -7.23 \\
\hline A & -7.31 & -6.36 & $\mathrm{C}$ & -3.98 & -8.11 & $\mathrm{C}$ & -4.89 & -6.62 \\
\hline A & -7.03 & -8.33 & $\mathrm{C}$ & -3.11 & -7.81 & $\mathrm{C}$ & -4.98 & -7.16 \\
\hline A & -7.23 & -8.10 & $\mathrm{C}$ & -1.38 & -8.60 & $\mathrm{C}$ & -5.17 & -6.95 \\
\hline A & -7.12 & -4.78 & $\mathrm{C}$ & -2.28 & -8.06 & $\mathrm{C}$ & -5.08 & -7.43 \\
\hline A & -7.50 & -9.70 & $\mathrm{C}$ & -5.25 & -8.43 & $\mathrm{C}$ & -4.95 & -7.27 \\
\hline A & -5.96 & -7.96 & $\mathrm{C}$ & -3.50 & -7.38 & B & -7.01 & -7.00 \\
\hline A & -6.03 & -6.34 & $\mathrm{C}$ & -3.25 & -7.30 & B & -7.38 & -7.64 \\
\hline A & -6.87 & -7.59 & $\mathrm{C}$ & -4.22 & -7.48 & B & -7.77 & -7.65 \\
\hline A & -4.51 & -6.35 & $\mathrm{C}$ & -5.71 & -6.75 & B & -7.47 & -7.79 \\
\hline A & -5.97 & -8.32 & $\mathrm{C}$ & -6.09 & -7.82 & B & -6.54 & -7.29 \\
\hline A & -4.68 & -7.49 & $\mathrm{C}$ & -5.51 & -7.08 & B & -6.98 & -6.86 \\
\hline A & -6.87 & -4.65 & $\mathrm{C}$ & -6.00 & -6.98 & B & -7.06 & -7.15 \\
\hline A & -7.02 & -6.18 & $\mathrm{C}$ & -9.26 & -7.88 & B & -7.05 & -7.01 \\
\hline A & -6.68 & -5.98 & $\mathrm{C}$ & -3.19 & -8.60 & B & -7.12 & -6.97 \\
\hline B & -6.04 & -7.13 & $\mathrm{C}$ & -3.12 & -8.46 & B & -6.88 & -7.57 \\
\hline B & -6.41 & -7.37 & $\mathrm{C}$ & -2.67 & -8.46 & B & -5.38 & -7.87 \\
\hline B & -5.25 & -7.84 & $\mathrm{C}$ & -2.51 & -8.78 & B & -3.54 & -8.53 \\
\hline B & -6.37 & -8.01 & $\mathrm{C}$ & -2.34 & -9.44 & B & -3.23 & -8.42 \\
\hline B & -7.03 & -7.45 & C & -2.31 & -8.95 & B & -7.38 & -7.64 \\
\hline
\end{tabular}

are related to the scarps and the plain area of the plateau. There is only one age (Table I) for this area: 302 kyr BP. The Serra da Bodoquena succession is composed of Pleistocene and Holocene carbonates, with tufas and brecciated wackestones in the basal part, overlying the basement (Fig. 2). These tufas crops out in several places of the ridge, always with sharp erosional contact, with the basement and with the carbonates above, related to the main faults of the Serra da Bodoquena, and the brecciated wackestones crop out in just a few areas, with a sharp erosional contact with the basement. The chronological data (Table I) show several stages of tufa deposition: $118 \mathrm{kyr}$ BP; $75 \mathrm{kyr}$ BP; 55 to 51 kyr BP.

\section{HOLOCENE DEPOSITS}

The Holocene deposits occur only in the Serra da Bodoquena and Pantanal do Miranda, with a basal erosional surface (Fig. 2). The Pantanal 
do Miranda carbonates are quartz sand-rich wackestones which overlie the quartz sands of the Pantanal Formation, forming numerous of carbonate lenses. The chronological data are poor (Table I), with only one age: 3,9 kyr BP. In Serra da Bodoquena, the Holocene carbonates covering the Pleistocene deposits include oncolithic packestone and fossil-rich wackestones that, with a sharp erosional contact, are overlain by tufas (Fig. 2). The chronological data (Table I) indicate several stages of carbonate deposition: 5.6 to $2.1 \mathrm{kyr}$ BP; $0.8 \mathrm{ky}$ $\mathrm{BP}$ to the present-day.

\section{FACIES}

The occurrences of continental carbonates reported here from the Serra da Bodoquena, Pantanal do Miranda, Corumbá/Ladário plateau and Serra das Araras are similar (Fig. 2), and they can be separated into seven sedimentary facies: Calcretized polymitic conglomerate - Cpc; Calcretized brecciated wackestone - Cbw; Oncolithic packestone - Op; Fossil-rich wackestone - Fw; Quartz sand-rich wackestone - Qw; Laminated tufa - Lt; Massive tufa - Mt. Despite the particularities of the studied region, most facies described here have been identified in other continental carbonate environments elsewhere (Arenas-Abad et al. 2000, 2007, Arenas et al. 2014, Carthew et al. 2003, Gandin and Capezzuoli 2008, Pla-Pueyo et al. 2009, Pla-Pueyo et al. 2015).

\section{CALCRETIZED POLYMITIC CONGLOMERATE - CPC}

The calcretized conglomerates (Cpc, Fig. 3a and 3b) were identified in Serra das Araras and in Corumbá/Ladário plateau, commonly outcropping in direct contact, an angular unconformity, with the basement, forming tabular beds that vary from 0.5 to $9 \mathrm{~m}$ thick, and can be observed in the Corumbá/ Ladário section (Fig. 2). It mostly consists of nonoriented, millimeter in diameter, quartz and feldspar grains along with lithic limestone clasts, which can be millimeters to centimeters in diameter (Fig. 3a), with ostracods fossils and micritic calcite between the grains, in a matrix-supported framework. (Fig. 3a). Some pedogenic features are observed, such as concentric cracks and root cavities, along with diagenetic features such as calcite spar and microspar cements and recrystallized matrix (Fig. $3 b)$.

\section{CALCRETIZED BRECCIATED WACKESTONE - CBW}

The only facies which can be recognized in all studied areas, except in Pantanal do Miranda, are the calcretized wackestones (Cbw, Fig. 3c and 3d), which crop out in direct contact, an angular unconformity, with the basement or directly overlying the facies $\mathrm{Cpc}$, with a gradational contact, forming tabular or lenticular beds that are 0.5 to $1 \mathrm{~m}$ thick. In the Serra das Araras section (Fig. 2) it can be observed that the facies Lt and Mt overlies some Cbw beds, and in Corumbá/Ladário plateau (Fig. 2), Cbw facies overlie some beds of Cpc. In Serra da Bodoquena (Fig. 2), Cbw crops out in direct contact, an angular unconformity, with the carbonate basement, and is commonly covered by facies Op and Fw, in gradational contact. This facies consists of quartz grains and limestone lithic fragments, ranging from sand to pebble, floating on a micritic matrix, grading upwards to a intraclastic wackestone, represented by centimetric micritic clasts (Fig. 3c). Displacive/replacive texture can be observed as calcite spar filling textures, along with pisolithic and nodular textures (Fig. 3d), similar to beta-texture patterns. It also occurs matrix recristalization and $\mathrm{Fe} / \mathrm{Mn}$ cementation (Fig. 3d).

ONCOLITHIC PACKESTONE - OP

The oncolithic packestones (Op, Fig. 3e and 3f) are restricted to Serra da Bodoquena, and form lenticular bodies, up to $0.5 \mathrm{~m}$ thick, which are positioned, with gradational contact, between facies $\mathrm{Cbw}$ and $\mathrm{Fw}$, as shown in Serra da Bodoquena 

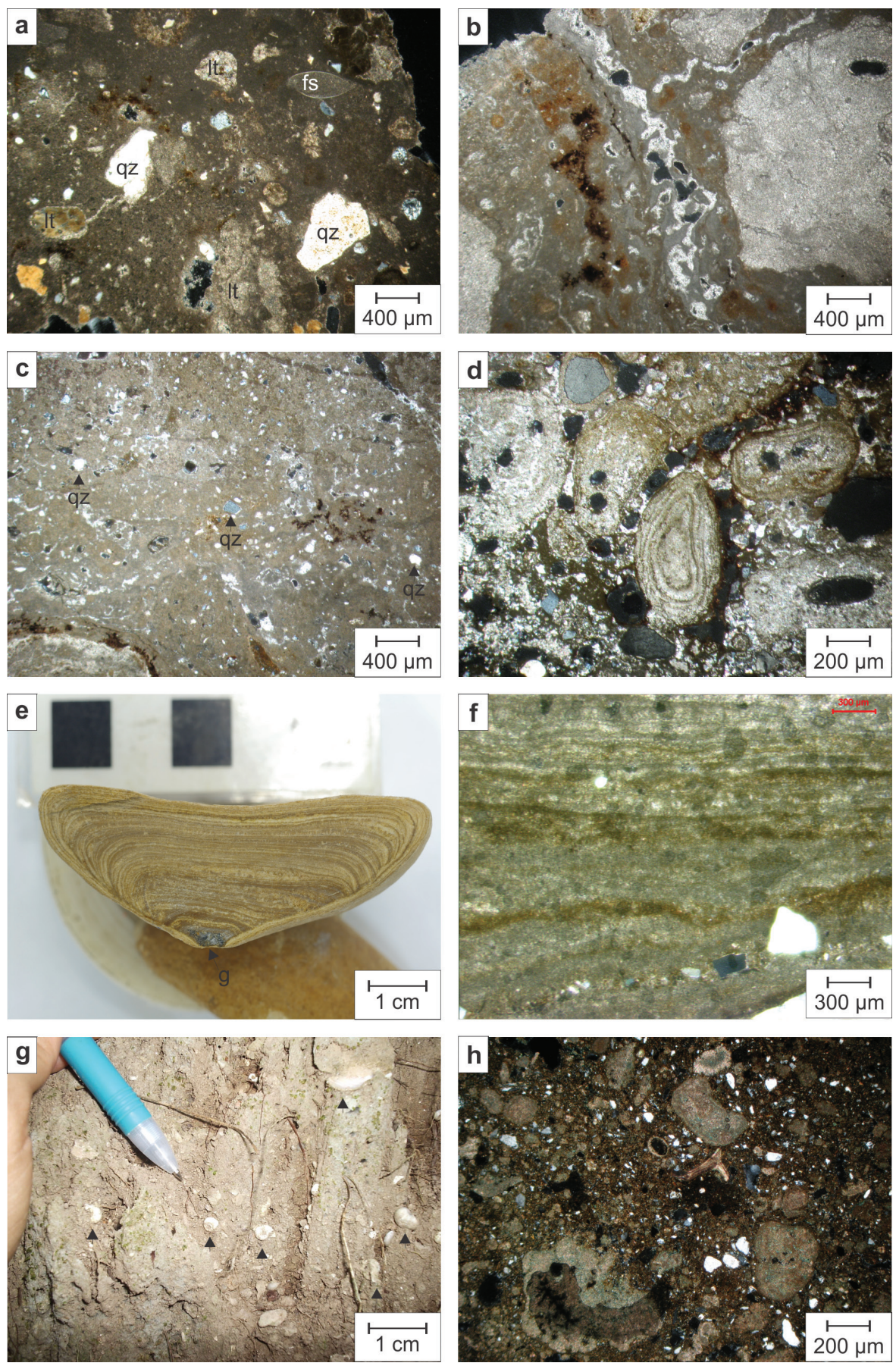

Figure 3 - Plate showing photographs and microscopic photographs (optical microscope) of lower facies. a: Microscopic photograph (polarized) of wackestone with fossils (calcrete), clasts are quartz (qz), lithics (lt) and fossils of ostracods (fs) (Corumbá, MS). b: Microscopic photograph (polarized) of wackestone with fossils (calcrete), root cavity (Corumbá/Ladário plateau). c: Microscopic photograph (polarized) of wackestone (calcrete), clasts are quartz (qz) and lithics (lt) (Serra das Araras). d: Microscopic photograph (polarized) of asymmetric coated grains with Fe cementation (Serra das Araras). e: Photograph of internal structures of an asymmetric oncolite with highlighted start up grain (g) (Serra da Bodoquena). f: Microscopic photograph (polarized) of asymmetric oncolite showing planar depositional structures (Serra da Bodoquena). g: Photograph of fossiliferous wackestone with gastropods fossils highlighted (arrows) (Serra da Bodoquena). h: Microscopic photograph (polarized) of low crystallized fossiliferous wackestone (Serra da Bodoquena). 
section (Fig. 2). It consists of concave-convex calcitic oncolites, $4 \mathrm{~cm}$ in diameter (Fig. 3e), dense laminated, but not concentrically, with the micritic laminae covering an initial sand grain of quartz or limestone. They are always found with the same orientation, with the convex side turned down (Fig. 3f). An unconsolidated micritic matrix is present between the oncolites. All the depositional features are preserved, with no sign of pedogenic or diagenetic modifications.

\section{FOSSIL-RICH WACKESTONE - FW}

The fossil-rich wackestones (Fw, Fig. 3g and 3h) are an exclusive facies of Serra da Bodoquena in the form of tabular and lenticular beds, which are 0.5 to $3 \mathrm{~m}$ thick. This facies always crop out over facies $\mathrm{Cbw}$ and $\mathrm{Op}$, and are commonly covered by facies Lt and Mt, which can be observed in Serra da Bodoquena section (Fig. 2). The fossil content of this facies is notable in macroscopic observation, with many mollusk shells widespread in the sediment (Fig. 3g). This wackestone is composed by unconsolidated micritc sediment, with low content $(\sim 10 \%)$ of quartz, feldspar and lithic limestones grains, along with fossil plant fragments and bivalve and gastropods fossil shells (Fig. 3h). A low ( $1 \%$ ) portion of the micrite of this wackestone is recrystallized, and just traces of $\mathrm{Fe} / \mathrm{Mn}$ cement can be found.

\section{QUARTZ SAND-RICH WACKESTONE - QW}

This facies can only be recognized in Pantanal do Miranda area, and are composed by wackestones (quartz sand rich) (Qw, Fig. 4a and 4b), which form lenses, 0.5 to $1 \mathrm{~m}$ thick. The contact between Qw and Pantanal Formation is abrupt, as shown in Pantanal do Miranda section (Fig. 2). It consists of wackestone, with micritic matrix and high content $(\sim 30 \%)$ of quartz sand grains and macroscopic notable content fossils of gastropods and algae (Fig. 4a). Pedogenic features were observed, such as root cavities and empty cracks (Fig. 4b). Despite some recrystallized portions of the matrix can be identified, no representative occurrence of cement was noted.

TUFAS - LAMINATED - LT AND MASSIVE - MT

The tufas facies (Lt and Mt, Fig. 4c to 4f) commonly appear isolated or interbedded (filling fractures), in direct contact, with the carbonate basement forming an angular unconformity, as lenses 0.5 to $3 \mathrm{~m}$ thick related to springs and fluvial channels. Facies Lt and Mt can also overlie facies $\mathrm{Cbw}$ and $\mathrm{Fw}$ with erosional contact which can be observed in Serra da Bodoquena and Serra das Araras sections (Fig. 2). The Lt facies is composed by microspar calcite stromatolitic lamination, with presence of encrusted microbes and macrophytes fossils and icnofossils (Fig. 4c). The presence of clay-minerals associated with the calcite spar is common, and occurs more concentrated in some laminae. Diagenetic features are represented by calcite cement, in an intense $(\sim 20 \%)$ cementation of fossil pores (Fig. $4 d$ ). The Mt facies occurs associated with facies Lt, and also occurs only in Serra da Bodoquena and Serra das Araras (Fig. 4e). It consists of stems, levees and seeds, ranging from $0.5 \mathrm{~mm}$ to $20 \mathrm{~cm}$ in major axis, encrusted or substituted by microspar calcite (Fig. 4f). High porosity ( $20 \%)$ is the characteristic feature due to organic matter decomposition (encrusted fossils). No pedogenic features were observed and low $(\sim 10 \%)$ calcite cementation can be observed.

\section{FACIES ASSOCIATIONS}

It was possible to group the facies recognized in the studied areas into facies associations, related to each location which represents depositional paleoenvironments. Three facies associations were described in the field (Fig. 2): alluvial fan (A), lacustrine/palustrine (B) and fluvial channel/ springs $(\mathrm{C})$. 

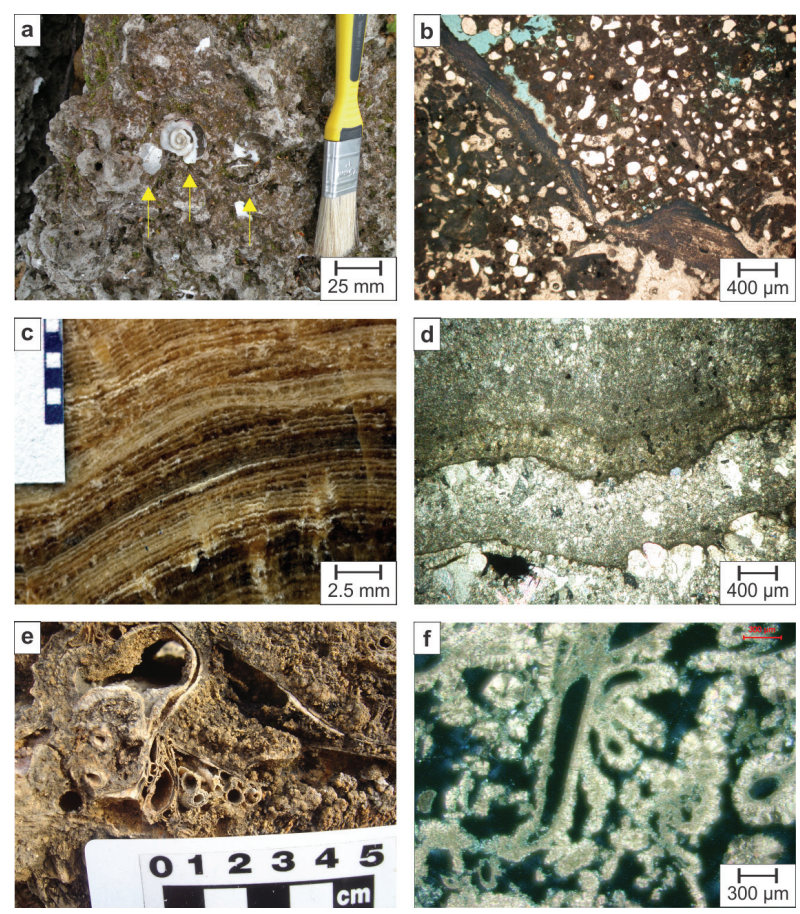

Figure 4 - Plate showing photographs and microscopic photographs (optical microscope) of upper facies. a: Photograph of quartz wackestone with gastropods fossils (arrows) (Pantanal do Miranda). b: Microscopic photograph of quartz wackestone with fossils (calcrete) with preserved root cavity (Pantanal do Miranda). c: Photograph of laminated boundstone (tufa, with well-marked stromatolitic lamination (Serra da Bodoquena). d: Microscopic photograph (polarized) of laminated boundstone (tufa) showing cementation and recrystallization (Serra da Bodoquena). e: Photograph of massive boundstone (tufa) showing macrophytes fossils (Serra da Bodoquena). f: Microscopic photograph (polarized) of massive boundstone (tufa) with biological porosity (macrophytes and microphytes) (Serra da Bodoquena).

\section{ALLUVIAL FAN (A)}

This facies association is present in Serra das Araras and in Corumbá/Ladário plateau and is composed of facies Cpc (Fig. 3a and 3b) and the Neoproterozoic carbonate basement (Fig. 2). Besides a coarse grained lithological composition, an important feature of these deposits is the actual outcrop position close to scarps, upon the basement, with a variable thickness from $15 \mathrm{~cm}$ to $10 \mathrm{~m}$, and also variable in extent from $100 \mathrm{~m}^{2}$ to 50 $\mathrm{km}^{2}$. These deposits are cut by sub-vertical normal faults $(E-W)$, parallel to the plateau scarps. Some textures and structures, especially the displacive calcite filling (Fig. 3b), related to the near-surface parts, are the result of pedogenic alteration. The characteristics of facies association $\mathrm{A}$ indicates deposition from high-energy debris flows, with sufficient energy to erode the basement and previous lacustrine carbonate deposits. The poor sorting of clasts, in a fine matrix with fossils, is similar to conglomerates deposited by gravity in proximal, submerged areas of lacustrine systems (Fig. 3a).

\section{LACUSTRINE/PALUSTRINE (B)}

This facies association includes facies Cbw (Fig. $3 \mathrm{c}$ and $3 \mathrm{~d}$ ), Op (Fig. 3e and $3 \mathrm{f}$ ) and Fw (Fig. $3 \mathrm{~g}$ and $3 \mathrm{~h}$ ) and occurs in Serra do Bodoquena, with facies Cbw, Op and Fw, and Corumbá/Ladário plateau, with facies $\mathrm{Cbw}$, which has a gradational contact with facies association A (Fig. 2). The thickness of this association ranges between 15 $\mathrm{cm}$ to $6 \mathrm{~m}$ and its area ranges between $50 \mathrm{~m}^{2}$ and $20 \mathrm{~km}^{2}$. Facies association B is compatible with lacustrine environment because it is dominated by micritic carbonate (Cbw, Op, Fw), with ostracods, gastropods and bivalves in facies Fw (Fig. 3h), located in flat areas at the foot of the hills, in form of discontinuous and elongated lenses. The facies Op is related to the development of oncolites in shallow and low-energy environments, as suggested by the asymmetry and texture of laminae (Fig. 3f). The facies Qw (Fig. 4a and 4b) is related to a palustrine environment that formed small water bodies exclusively in Pantanal do Miranda, with thickness ranging between 1.5 and $5 \mathrm{~m}$, and average area around $200 \mathrm{~m}^{2}$. The textures include rhizoliths and mud cracks (Fig. 4b) and the well-rounded and well sorted quartz grains. The biological activity in this environment was high, with remarkable fossil gastropods and preserved roots (Fig. 4a and 4b). 


\section{FLUVIAL CHANNEL/SPRINGS (C)}

Facies association $\mathrm{C}$ includes facies Lt (Fig. 4c and 4d) and Mt (Fig. 4e and 4f) and is related to the basement (Fig. 2). The channels show typical concave-up erosional morphology, filled with clastic carbonate sediments. The geometry in Serra das Araras is related to lenses, $3 \mathrm{~m}$ thick, distributed in an elongated area, with an average width of $75 \mathrm{~m}$ and extension of up to $2 \mathrm{~km}$. In Serra da Bodoquena these deposits vary in thickness, from $15 \mathrm{~cm}$ to 6 $\mathrm{m}$, and in area, from $20 \mathrm{~m}^{2}$ to $1 \mathrm{~km}^{2}$, and are always associated with active and inactive fluvial channels. Some tufas textures, such as petrified waterfalls geometry, appears related to the carbonate scarps (Ford and Pedley 1996). The tufas, resulting from carbonate precipitation associated with springs, with laminated tufa ( $\mathrm{Lt}$ ) deposited next to spring areas, and fine carbonate (Cbw) (Fig. 3c) deposited downstream. The petrified waterfalls geometry of facies Lt suggests high hydraulic energy (Corrêa et al. 2011). This association is not observed in the Corumbá/Ladário plateau, but some tufa clasts, similar to facies Lt, were identified.

\section{STABLE ISOTOPE COMPOSITION}

The various carbonate facies of Serra das Araras, Corumbá/Ladário plateau, Pantanal do Miranda and Serra da Bodoquena $(\mathrm{n}=71)$ have stable isotope compositions that range between $-9.44 \%$ o and $-4.20 \%$ V-PDB (mean $=-7.14 \pm 0.90 \%$ ) for $\delta^{18} \mathrm{O}$, and between $-9.26 \%$ and $-1.39 \%$ V-PDB (mean $=-5.79 \pm 1.53 \%$ ) for $\delta^{13} \mathrm{C}$ (Table II; Fig. 5).

These results are similar to those obtained for other continental carbonates (Andrews et al. 2000, 1997, Arenas and Alonso-Zarza 2004, Boggiani et al. 1999, Buccino et al. 1978, Chafetz and Lawrence 1994, Fritz 1965, Horvatincic et al. 2003, Sinha et al. 2006). In detail, the average $\delta^{13} \mathrm{C}$ for the Pleistocene samples is more negative than the Holocene samples (Pleistocene $\mathrm{n}=24$; mean $\delta^{13} \mathrm{C}=-6.64 \pm 0.59 \%$; Holocene $\mathrm{n}=49$; mean $\delta^{13} \mathrm{C}=-5.38 \pm 1.78 \%$ ), with less variation. The average $\delta^{18} \mathrm{O}$ values are similar $(-6.99 \pm 0.97 \%$ for Pleistocene and $-7.21 \pm 1.24 \%$ for Holocene), with a wider range for Holocene samples.

Another difference is the most negative $\delta^{13} \mathrm{C}$ mean value for the lacustrine facies association (C) in the Holocene $(-7.31 \pm 0.48)$ compared to the same facies association in the Pleistocene $(-6.64 \pm 0.59)$. These results could suggest an increase in vegetation (Andrews 2006), perhaps the consequence of an increase in rainfall during the Holocene, which is in accordance with paleoclimatic data for the region (Bertaux et al. 2002, Whitney et al. 2011).

The correlation between the $\delta^{13} \mathrm{C}$ and $\delta^{18} \mathrm{O}$ values for the Pleistocene samples is $r=0.01$ and for the Holocene samples is $r=0.68$. The lack of a correlation in the Pleistocene data could be a reflection of sedimentation in a hydrologically closed system, with a strong groundwater influence (Arenas-Abad et al. 2000, 2007, Garnett et al. 2006). However, in spite of such a poor correlation, the set of Holocene samples shows a moderately good covariation, with $r=0.68$; this could also indicate a hydrologically open system, but with more evaporation and/or CO2 degassing (Andrews 2006). It was not possible to analyse the isotopic variation through time, because the sampling for stable isotopes was not related to the sampling for dating. The only remarkable fact is the large variation in the $\delta^{13} \mathrm{C}$ and $\delta^{18} \mathrm{O}$ values in the Pleistocene, probably related to changing residence time of the water in lakes and the influence of organic matter, possibly due to variations in precipitation and evaporation during this epoch (Arenas et al. 2014).

\section{DISCUSSION}

The described facies associations of the continental carbonates of Serra das Araras, Corumbá/ Ladário plateau, Pantanal do Miranda and Serra da Bodoquena are similar to other Quaternary 
sequences described in different sedimentary settings (Arenas-Abad et al. 2000, Arenas-Abad et al. 2007, Pimentel et al. 1996, Pla-Pueyo et al. 2009, 2015). However, the combination of sedimentary systems described here by the facies associations and the prevailing tropical climate for the region during the Quaternary is rare.

The characteristics of facies association $\mathrm{A}$ is interpreted as deposition by debris flows into lakes. This interpretation is consistent with the fact that the facies association $A$ has a transitional contact with facies association $\mathrm{B}$, related to lacustrine sedimentation, and with the fossil content. Similar features are described in alluvial environments in Spain, Sorbas basin, where conglomerates similar to facies $\mathrm{Cpc}$ were attributed to debris flows (Candy et al. 2003). The interruption of deposition is marked by an erosional surface, which also indicates sub-aerial exposure and soil formation, generating displacive textures (Fig. 3b) similar to calcretes exposed to biological activity (AlonsoZarza 2003). The facies association A is only related to the Pleistocene occurrences, which might be related to changes in the environmental conditions, especially in geomorphology and climate, which is discussed below.

The facies association $\mathrm{B}$ is interpreted as formed by lacustrine deposition due to textural characteristics and fossil content, similar to the lacustrine deposits of wackestones described in the Madrid basin (Spain) (Wright et al. 1997). The deposits of this facies association can be related to the Pleistocene sequences (facies $\mathrm{Cbw}$ ) or to the Holocene (facies Op and Fw), and the contact between these sequences is marked by an erosional surface, which also indicates sub-aerial exposure (Figs. 3c and 3d). The occurrence of the facies Op is also related to lacustrine environments, due to the asymmetrical characteristics of the oncoids, which are similar to the oncoids described in the Mainz Basin, Germany (Leinfelder and Hartkopf-FröDer 1990). The characteristics of the facies association
B, in Pantanal do Miranda, is interpreted as the deposition in palustrine settings, due to the carbonate lenses form and their fossil content (Figs. $4 \mathrm{a}$ and $4 \mathrm{~b}$ ). The inclusion of quartz sand can be related to wind transport during the deposition of the carbonates, due to the quartz sand composition of the Pantanal Formation, leading to specific facies that can also be found in the Atacama Basin, Chile (Bell 1989) and in the Sado Basin, Portugal (Pimentel et al. 1996).

For the facies association $\mathrm{C}$, in Serra das Araras, the interpretation of springs, related to the basement and/or to the facies $\mathrm{Cpc}$ and $\mathrm{Cbw}$, the tufas formed over theses rocks as speleothems and perched spring lines (Ford and Pedley 1996), in a similar situation to what is observed in Denizli Province, Turkey (Özkul et al. 2010). The facies Cbw also present textures compatible with subaerial exposure and soil formation (Figs. 3c and $5 \mathrm{~d})$, also with displacive texture. The development of tufas in Serra da Bodoquena, related to channels is interpreted as fluvial deposition for the facies association $\mathrm{C}$, in a common setting in different fluvial environments (Arenas et al. 2014, Emeis et al. 1987, Martini and Capezzuoli 2014). The two facies, Mt and Lt, are related to specific environments: the facies Lt is related to high energy water flow environments, where the $\mathrm{CO}_{2}$ degassing has a major control, leading to the precipitation of laminated tufas (Arenas et al. 2014, Chen et al. 2004); the facies Mt is related to the low energy environments, where the incrustation of algae, mosses and plants is possibly due to the low energy of water flow (Zhang et al. 2001, Arenas et al. 2014).

\section{FACTORS CONTROLLING THE CONTINENTAL CARBONATES GENESIS AND EVOLUTION}

The south-central region of the Pantanal Basin and its surroundings have a geological, geomorphological and environmental situation that favoured the deposition of carbonates towards the 
end of the Quaternary and which, at least in part, are continuing to form at the present time.

These carbonate deposits do not show any particular features that allow an interpretation of a pure climatic control on their deposition. For example, no evaporitic minerals were identified in the lacustrine deposits, which could indicate deposition under dry conditions, as has been recorded in many lacustrine successions of arid regions (Camoin et al. 1997). An element that could be used as an indicator of paleoclimatic changes is the erosional surface with modifications produced by subaerial exposure, present at the top of Pleistocene section. Although calcretes can develop under many climatic conditions (AlonsoZarza and Wright 2010), the features identified in this study are not conclusive regarding how deep these modifications were and how representative the calcrete generation is in terms of a paleoclimatic interpretation. This is particularly revealed by the presence of beta texture, whose formation involves biogenic activity in pedogenic profiles (AlonsoZarza 2003, Wright and Tucker 1991), which can occur in different climatic environments.

The values of stable isotopes are compatible with sub-humid/humid conditions during the development of tufas ( $\mathrm{Lt}$ and $\mathrm{Mt}$ ) and lake sediments (Op and Fw) (Fig. 5). Some samples of lake sediments (facies Qw) have values positioned between tufa and calcretes fields, but with more negative $\delta_{13} C$ (Fig. 5) (Alonso-Zarza 2003). This occurred, probably, because these sediments are exposed to subsequent dry periods, which eventually could lead to calcretization processes (Wright and Tucker 1991). For the facies with subaerial modification ( $\mathrm{Cpc}$ and $\mathrm{Cbw}$ ), the results are not as consistent as expected for calcretes in other parts of the world (Alonso-Zarza 2003), since the results showed a concentration of values in an area between carbonates with sub-aerial exposure and mature calcretes (Fig. 5). This might be related to exposure to subsequent humid and arid periods, which would have caused the precipitation of carbonate cements in diverse climatic conditions.

Climate change events might have conditioned the carbonate sedimentation in the Pantanal area where a more humid climate led to the formation of lakes and river systems, and a drier climate led to the development of erosional surfaces and subaerial exposure. Thus, a period of higher humidity would have favoured the establishment of lakes that were later dried under conditions related to arid climate, culminating in the formation of the erosional surfaces with sub-aerial exposure features.

After this arid event, a humid event would have again favoured the development of lakes and river systems. This alternation might have been occurring since the Middle Pleistocene. Tectonics is another factor that was probably significant in the genesis of carbonates in the Pantanal region. This is suggested by the direct association between the carbonate deposits and tectonic structures, normal faults and folds originated in the Brasiliano tectonic cycle, in the Neoproterozoic (Almeida et al. 2000), and reactivated with the Andean orogeny and the subsidence of the Pantanal (Ussami et al. 1999). The tectonic activity could have modified the relief, generating scarps and depressed areas, which controlled the location of rivers and lakes. The faults were the conduits for carbonated water derived from the basement and, when generating high-gradient scarps, provided a turbulent flow with consequent high $\mathrm{CO}_{2}$ degassing, similar to the situation in the Iberian Range (Peña et al. 2000). The evolution of the local geomorphology was mostly conditioned by tectonics and weathering, creating plateaus, scarps and ranges (serras), allowing the development of fluvial and lacustrine systems.

In the Serra das Araras, the influence of the structures on the genesis of carbonates is demonstrated by their geometry and position, characterized by elongated bodies of $\mathrm{Cpc}, \mathrm{Cbw}$, Lt and Mt facies parallel to the base of a fault 


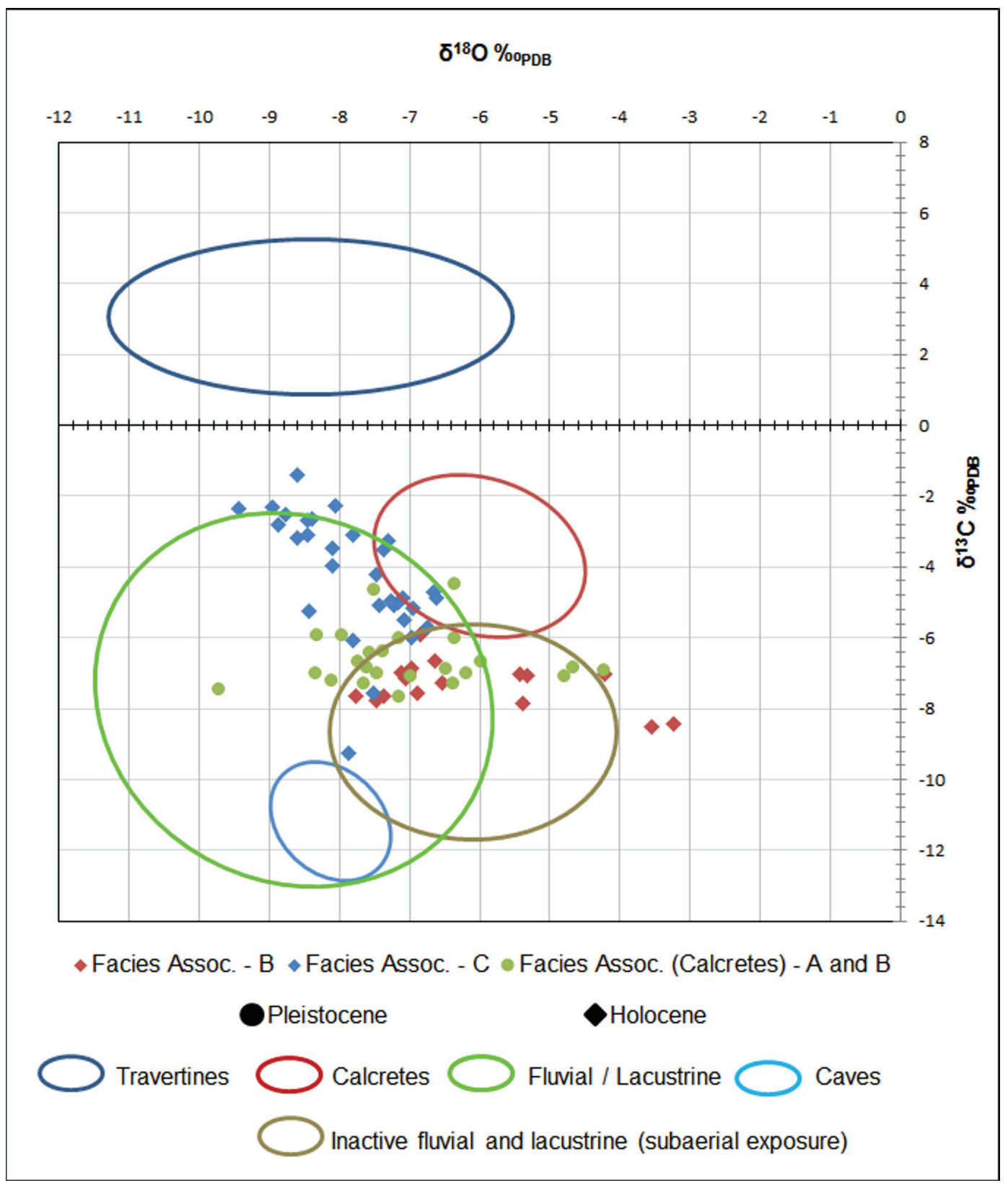

Figure 5 - Isotopic composition $\left(\delta^{13} \mathrm{C}\right.$ and $\left.\delta^{18} \mathrm{O}\right)$ of different facies associations and combined plot of $\delta^{13} \mathrm{C}$ and $\delta^{18} \mathrm{O}$ data from other continental carbonates. Data sources: Andrews et al. 1997, 2000, Arenas et al. 2004, Boggiani et al. 1999, Buccino et al. 1978, Chafetz and Lawrence 1994, Fritz 1965, Horvatinčić et al. 2003, Sinha et al. 2006. 
scarp (NE-SW). In the Corumbá/Ladário plateau the occurrence of several small elongated bodies of $\mathrm{Cpc}$ and $\mathrm{Cbw}$ facies related to faults (NE-SW in the north and NW-SE in the south) is also observed . In the Serra da Bodoquena the most significant deposits of Fw, Lt and Mt facies that form an elongated body bordered in the east by a fault (NE$\mathrm{SW})$, with thickness $(\sim 10 \mathrm{~m})$ deposited in less than 6,000 years ago. According to the tectonic hypothesis, elongated lakes were created during the subsidence of areas along tectonic structures where debris flows were also common in marginal areas. With the tectonic evolution, the faults produced significant topographical variation with plateaus and steep cliffs allowing the development of riverine systems with springs, waterfalls and channels.

\section{PALEOENVIRONMENTAL EVOLUTION}

The analysis of the depositional record in the studied area indicates that the first phase of development of lacustrine systems occurred directly on the carbonate basement, in the Middle Pleistocene (Table I). The formation of these lakes occurred after an extended period of non-deposition and/or erosion, during which there was the development of an unconformity on the surface of the basement. The greater thickness of lacustrine deposits was recorded on the Corumbá/Ladário plateau, where the marginal areas of the lakes received sediments transported by gravitational flows, which reworked previously deposited sediments and carbonates of the basement. In the Serra das Araras, there was also development of tufas curtains on the cliffs, in association with springs, along with the development of elongated lakes, associated to the base of the cliffs, with restricted debris flows sediments. The development of packages with deposits of subaqueous debris flows on the Corumbá/Ladário plateau and Serra das Araras may have also been promoted by gravity instabilities in low-energy environments such as lakes, due to the accumulation of sediment near the base of the fault scarps. Generation of the fault scarps or its reactivation was caused by the subsidence events of the Pantanal Basin.

In the Serra da Bodoquena, the fluvial and spring tufa (Late Pleistocene), occurring immediately over the basement, and in the Serra das Araras the sedimentation took place exclusively in springs. In the Corumbá/Ladário plateau, no carbonate sedimentation occurs during the Holocene. The evolution of regional tectonics, with the subsidence of the Pantanal Basin, probably captured the drainages of the region, shifting the course of the main river, the Paraguay, to the surroundings of the Corumbá/Ladário plateau. In Serra da Bodoquena, the Holocene deposits are represented by the occurrence of lacustrine carbonate sediments and fluvial tufas until late Holocene when, probably due to geomorphological and climatological changes, the lacustrine systems disappeared and only the riverine systems remained active. The Pantanal do Miranda area only presents deposits related to the middle-late Holocene boundary (Walker et al. 2012). The observed palustrine system might be related to a change in the water table during the recent evolution of the Pantanal Basin, and is probably linked with climatic variations (Assine and Soares 2004). These lacustrine systems are still active in the neighbouring area of Nhecolândia (Furquim et al. 2010), in a distal part of the Taquari river alluvial fan, although evaporitic sediments were described.

\section{CONCLUSIONS}

The mapping of Quaternary continental carbonates in the Pantanal Basin and its surroundings, along with sedimentological, stratigraphic, isotopic and petrographic studies have allowed the proposal of a reconstruction of the depositional environments and the main factors involved in its genesis. 
The analyses of facies associations indicate deposition under continental conditions within subaqueous debris flows, springs, lakes and river channels. The stratigraphic correlation reveals that the deposits are not geographically or chronologically related, but the sedimentological similarities indicate repetition of environmental conditions in different times and areas in the studied region.

The presence of an erosional surface, formed due to sub-aerial exposure, indicates that the climatic regime was not stable during the development and evolution of these deposits. Considering climate hypothesis, higher humidity would have favoured the establishment of lakes that were later dried, generating the erosional surface and the sub-aerial exposure features in the sediments. After this, the hydrological regime would have again favoured the development of lakes and river systems, in a more humid climate. This alteration of arid and humid climate has occurred since the Middle Pleistocene.

The geological structures associated with active tectonic are a key factor in the formation of the studied Quaternary carbonates. These deposits do not occur randomly in the areas studied, but are related to fault zones. The occurrence of subaqueous debris flows in lacustrine environment, as described in the Corumbá/Ladário plateau, may have also been related to gravitational instability during sedimentation. Additionally, there was deposition in springs and waterfalls in river channels due to the presence of topographic variations related to tectonic activity.

\section{ACKNOWLEDGMENTS}

The authors would like to thank the financial support, for the post-graduation (Master and $\mathrm{PhD}$ ) of the first author, provided by the Coordination for the Improvement of Higher Education Personnel Coordenação de Aperfeiçoamento de Pessoal de Nível Superior(CAPES) and the Conselho Nacional de Desenvolvimento Científico e Tecnológico (CNPq 479500/2007-0). The acknowledgements are extensive to Nicolas Strikis, Francisco Cruz Jr. and Santiago Giralt for their support on U/ Th dating. We thank Paulo Cesar Boggiani for the mentorship and discussions provided during the development of the present work. Ana Maria Alonso-Zarza, Giovanna Dellaporta and Maurice Tucker are thanked for useful comments to improve the article.

\section{REFERENCES}

ALMEIDA FFM. 1945. Geologia do Sudoeste MatoGrossense. Bol da Div Geol e Mineral DNPM 116: 1-118.

ALMEIDAFFM. 1954. Geologia do Centroeste Matogrossense. Bol da Div Geol e Mineração, DNPM 150: 1-97.

ALMEIDA FFM. 1965. Geologia da Serra da Bodoquena (Mato Grosso), Brasil. Bol Geol e Mineral DNPM 219: $1-96$.

ALMEIDA FFM, BRITO NEVES BB AND DAL RÉ CARNEIRO C. 2000. The origin and evolution of the South American Platform. Earth-Science Rev 50: 77-111.

ALMEIDA LHS, SALLUN FILHO W, KARMANN I AND BOGGIANI PC. 2011. Quaternary tufas in the Serra do André Lopes, southeastern Brazil. Rend Online della Soc Geol Ital 16: 5-6.

ALONSO-ZARZA AM. 2003. Palaeoenvironmental significance of palustrine carbonates and calcretes in the geological record. Earth-Science Rev 60(3): 261-298.

ALONSO-ZARZA AM, MELÉNDEZ A, MARTÍN-GARCÍA R, HERRERO MJ AND MARTÍN-PÉREZ A. 2012. Discriminating between tectonism and climate signatures in palustrine deposits: Lessons from the Miocene of the Teruel Graben, NE Spain. Earth-Science Rev 113: 141160.

ALONSO-ZARZA AM AND TANNER LH. 2010. Carbonates in Continental Settings: Facies, Environments, and Processes. Developments in Sedimentology. Elsevier, Amsterdam, $400 \mathrm{p}$.

ALONSO-ZARZA AM AND WRIGHT VP. 2010. Calcretes. In: Alonso-Zarza AM and Tanner LH (Eds), Carbonates in Continental Settings: Facies, Environments and Processes. Elsevier, Amsterdam, p. 225-267.

ALVARES CA, STAPE JL, SENTELHAS PC, DE MORAES GONÇALVES JL AND SPAROVEK G. 2013. Köppen's climate classification map for Brazil. Meteorol Zeitschrift 22: 711-728.

ANDREWS JE. 2006. Palaeoclimatic records from stable isotopes in riverine tufas: Synthesis and review. EarthScience Rev 75: 85-104. 
ANDREWS JE, PEDLEY M AND DENNIS PF. 2000. Palaeoenvironmental records in Holocene Spanish tufas: a stable isotope approach in search of reliable climatic archives. Sedimentology 47: 961-978.

ANDREWS JE, RIDING R AND DENNIS PF. 1997. The stable isotope record of environmental and climatic signals in modern terrestrial microbial carbonates from Europe. Palaeogeogr Palaeoclimatol Palaeoecol 129: 171-189.

ARENAS-ABAD C, CABRERA L AND RAMOS E. 2007. Sedimentology of tufa facies and continental microbialites from the Palaeogene of Mallorca Island (Spain). Sediment Geol 197: 1-27.

ARENAS-ABAD C, GUTIÉRREZ F, OSÁCAR C AND SANCHO C. 2000. Sedimentology and geochemistry of fluvio-lacustrine tufa deposits controlled by evaporite solution subsidence in the central Ebro Depression, NE Spain. Sedimentology 47: 883-909.

ARENAS C AND ALONSO-ZARZA AM. 2004. Cenozoic calcretes from the Teruel Graben, Spain: microstructure, stable isotope geochemistry and environmental significance. Sediment Geol 167: 91-108.

ARENAS C, VÁZQUEZ-URBEZ M, PARDO G AND SANCHO C. 2014. Sedimentology and depositional architecture of tufas deposited in stepped fluvial systems of changing slope: Lessons from the Quaternary Añamaza Valley (Iberian Range, Spain). Sedimentology 61: 133171.

ASSINE ML, MERINO ER, PUPIM FN, WARREN LV, GUERREIRO RL AND MCGLUE MM. 2015. Geology and Geomorphology of the Pantanal Basin. In: Bergier I and Assine LM (Eds), Dynamics of the Pantanal Wetland in South America. Springer International Publishing, p. 23-50.

ASSINE ML AND SOARES PC. 2004. Quaternary of the Pantanal, west-central Brazil. Quat Int 114: 23-34.

AULER AS AND SMART PL. 2001. Late Quaternary Paleoclimate in Semiarid Northeastern Brazil from U-Series Dating of Travertine and Water-Table Speleothems. Quat Res 55: 159-167.

BASILICI G, DAL BÓ PFF AND LADEIRA FSB. 2009. Climate-induced sediment-palaeosol cycles in a Late Cretaceous dry aeolian sand sheet: Marília Formation (North-West Bauru Basin, Brazil). Sedimentology 56: 1876-1904.

BELL CM. 1989. Saline lake carbonates within an Upper Jurassic-Lower Cretaceous continental red bed sequence in the Atacama region of northern Chile. Sedimentology 36: 651-663.

BERTAUX J, SONDAG F, SANTOS R, CORNEC FL, SEIDEL A AND CAUSSE C. 2002. Paleoclimatic record of speleothems in a tropical region: study of laminated sequences from a Holocene stalagmite in Central-West Brazil. Quatern Int 89: 3-16.
BOGGIANI PC AND ALVARENGA CJS. 2004. Faixa Paraguai. In: Mantesso-Neto V, Bartorelli A, Carneiro ADR and Brito-Neves BB (Eds), Geologia Do Continente Sul-Americano: Evolução Da Obra de Fernando Flávio Marques de Almeida. Beca Editora, São Paulo, p. 113-122. BOGGIANI PC AND COIMBRA AM. 1995. Quaternary limestone of Pantanal area, Brazil. An Acad Bras Cienc 67: 343-349.

BOGGIANI PC, COIMBRA AM, GESICKI AL, SIAL AN, FERREIRA VP, RIBEIRO FB AND FLEXOR JM. 1999. Tufas Calcárias da Serra da Bodoquena. Sítios Geológicos e Paleontológicos do Brasil. http://sigep.cprm.gov.br/ sitio034/sitio034.htm Acesso em: 11 de março de 2016.

BOGGIANI PC, COIMBRA AM, RIBEIRO FB, FLEXOR JM, SIAL AN AND FERREIRA VP. 1998. Significado paleoclimático das lentes calcárias do Pantanal do Miranda - Mato Grosso do Sul. In: Anais do Congresso Brasileiro de Geologia. Sociedade Brasileira da Geologia, Belo Horizonte, p. 88.

BUCCINO G, D'ARGENIO B, FERRERI V, BRANCACCIO I, FERRERI M, PANICHI C AND STANZIONE D. 1978. I Travertini della bassa valle del Tanagro (Campania). Studio Geomorphologico, Sedimentologico e Geochimico. Boll della Soc Geol Ital 97: 617-646.

CAMOIN G, CASANOVA J, ROUCHY J-M, BLANCVALLERON M-M AND DECONINCK J-F. 1997. Environmental controls on perennial and ephemeral carbonate lakes: the central palaeo-Andean Basin of Bolivia during Late Cretaceous to early Tertiary times. Sediment Geol 113: 1-26.

CANDY I, BLACK S, SELLWOOD BW AND ROWAN JS. 2003. Calcrete profile development in Quaternary alluvial sequences, southeast Spain: Implications for using calcretes as a basis for landform chronologies. Earth Surf Process Landforms 28: 169-185.

CAPEZZUOLI E, GANDIN A AND PEDLEY M. 2014. Decoding tufa and travertine (fresh water carbonates) in the sedimentary record: The state of the art. Sedimentology 61(1): 1-21.

CARTHEW KD, TAYLOR MP AND DRYSDALE RN. 2003. Are current models of tufa sedimentary environments applicable to tropical systems? A case study from the Gregory River. Sediment Geol 162: 199-218.

CARTHEW KD, TAYLOR MP AND DRYSDALE RN. 2006. An environmental model of fluvial tufas in the monsoonal tropics, Barkly karst, northern Australia. Geomorphology 73: 78-100.

CHAFETZ HS AND LAWRENCE JR. 1994. Stable Isotopic Variability within Modern Travertines. Géographie Phys Quat 48: 257-273.

CHEN J, ZHANG DD, WANG S, XIAO T AND HUANG R. 2004 Factors controlling tufa deposition in natural waters at waterfall sites Sediment Geol 166: 353-366 
CORRÊA D, AULER AS, WANG X, EDWARDS RL AND CHENG H. 2011. Geomorphology and genesis of the remarkable Araras Ridge tufa deposit, Western Brazil. Geomorphology 134: 94-101.

CRUZ FW, BURNS SJ, KARMANN I, SHARP WD, VUILLE M, CARDOSO AO, FERRARI JA, DIAS PLS AND VIANA JR O. 2005. Insolation-driven changes in atmospheric circulation over the past 116,000 years in subtropical Brazil. Nature 434: 63-66.

DELLA PORTA G. 2015. Carbonate build-ups in lacustrine, hydrothermal and fluvial settings: comparing depositional geometry, fabric types and geochemical signature. Geol Soc London Spec Publ 418: 17-68.

DUNHAM RJ. 1962. Classification of carbonate rocks according to depositional texture. Classif Carbonate Rocks Am Assoc Pet Geol Mem 1: 108-121.

EMBRY AF AND KLOVAN JE. 1971. A Late Devonian reef tract on northeastern Banks Island, NWT. Bull Can Pet Geol 19(4): 730-781.

EMEIS KC, RICHNOW HH AND KEMPE S. 1987. Travertine formation in Plitvice National Park, Yugoslavia: chemical versus biological control. Sedimentology 34: 595-609.

FERNANDES LA AND BASILICI G. 2009. Transition of ephemeral palustrine to aeolian deposits in a continental arid - semi-arid environment (Upper Cretaceous Bauru Basin, Brazil). Cretac Res 30: 605-614.

FORD TD AND PEDLEY HM. 1996. A review of tufa and travertine deposits of the world. Earth-Science Rev 41: 117-175.

FRITZ P. 1965. Composizione isotopica dell'ossigeno e del carbonio nei travertini della Toscana. Boll di Geofis Teor ed Appl 7: 25-30.

FURQUIM S, GRAHAM RC, BARBIERO L, QUEIROZ NETO JP AND VIDAL-TORRADO P. 2010. Soil mineral genesis and distribution in a saline lake landscape of the Pantanal Wetland, Brazil. Geoderma 154: 518-528.

GAN MA, KOUSKY VE AND ROPELEWSKI CF. 2004. The South America Monsoon Circulation and Its Relationship to Rainfall over West-Central Brazil. J Clim 17: 47-66.

GANDIN A AND CAPEZZUOLI E. 2008. Travertine versus calcareous tufa: Distinctive petrologic features and stable isotopes signatures. Ital J Quat Sci 21: 125-136.

GARNETT ER, ANDREWS JE, PREECE RC AND DENNIS PF. 2006. Late-glacial and Early Holocene climate and environment from stable isotopes in Welsh tufa. Quaternaire 17(2): 31-42.

HORN BLD, PEREIRA VP AND SCHULTZ CL. 2013. Calcretes of the Santa Maria Supersequence, Middle Triassic, Rio Grande do Sul, Brazil: Classification, genesis and paleoclimatic implications. Palaeogeogr Palaeoclimatol Palaeoecol 376: 39-47.

HORVATINČIĆ N, OBELIC B AND BRONIC IK. 2003. Differences in the $14 \mathrm{C}$ age, $\delta 13 \mathrm{C}$ and $\delta 18 \mathrm{O}$ of Holocene tufa and speleothem in the Dinaric Karst. Palaeogeogr Palaeoclimatol Palaeoecol 193: 139-157.

LACERDA FILHO JV, VALENTE CR, LOPES RC, OLIVEIRA IWB, OLIVEIRA CC, SACHS LLB, SILVA VA AND BATISTA I. 2004a. Folha SF.21-Campo Grande. In: Schobbenhaus C, Gonçalves JH, Santos JOS, Abram MB, Leão Neto R, Matos GMM, Vidotti RM, Ramos MAB and Jesus JDA (Eds), Carta Geológica do Brasil Ao Milionésimo, Sistema de Informações Geográfica. CPRM, Brasília. http://rigeo.cprm.gov.br/xmlui/handle/ doc/8477 Acesso em: 2 de junho de 2016.

LACERDA FILHO JV, VALENTE CR, RIZZOTTO GJ, QUADROS MLES, LOPES RC, OLIVEIRA IWB, OLIVEIRA CC, SACHS LLB, SILVA VAAND BATISTA I. 2004b. Folha SE.21-Corumbá. In: Schobbenhaus C, Gonçalves JH, Santos JOS, Abram MB, Leão Neto R, Matos GMM, Vidotti RM, Ramos MAB and Jesus JDA (Eds), Carta Geológica do Brasil Ao Milionésimo, Sistema de Informações Geográfica. CPRM, Brasília. http://rigeo. cprm.gov.br/xmlui/handle/doc/17496 Acesso em: 2 de junho de 2016.

LEINFELDER RR AND HARTKOPF-FRÖDER, C. 1990. In situ accretion mechanism of concavo-convex lacustrine oncoids ('swallow nests') from the Oligocene of the Mainz Basin, Rhineland, FRG. Sedimentology 37: 287-301.

MARENGO JA ET AL. 2012. Recent developments on the South American monsoon system. Int J Climatol 32: 1-21.

MARTINI I AND CAPEZZUOLI E. 2014. Interdigitated fluvial clastic deposits and calcareous tufa testifying an uplift of the catchment area: An example from the Pianizzoli area (southern Tuscany, Italy). Sediment Geol 299: 60-73.

MCCREA JM. 1950. On the Isotopic Chemistry of Carbonates and a Paleotemperature Scale. J Chem Phys 18: 849-857.

NOVELLO VF, VUILLE M, CRUZ FW, STRÍKIS NM, DE PAULA MS, EDWARDS RL AND MOQUET JS. 2016. Centennial-scale solar forcing of the South American Monsoon System recorded in stalagmites. Scientific Reports 6: 24762.

ÖZKUL M, GÖKGÖZ A AND HORVATINČIĆ N. 2010. Depositional properties and geochemistry of Holocene perched springline tufa deposits and associated spring waters: a case study from the Denizli Province, Western Turkey. Geol Soc London Spec Publ 336: 245-262.

PEÑA JL, SANCHO C AND LOZANO MV. 2000. Climatic and Tectonic Significance of Late Pleistocene and Holocene Tufa Deposits in The Mijares River Canyon, Eastern Iberian Range, Northeast Spain. Earth Surf Process Landforms 25: 1403-1417.

PIMENTEL NL, WRIGHT VP AND AZEVEDO TM. 1996. Distinguishing early groundwater alteration effects from pedogenesis in ancient alluvial basins: examples from 
the Palaeogene of southern Portugal. Sediment Geol 105: $1-10$.

PLA-PUEYO S, GIERLOWSKI-KORDESCH EH, VISERAS C AND SORIA JM. 2009. Major controls on sedimentation during the evolution of a continental basin: PliocenePleistocene of the Guadix Basin (Betic Cordillera, southern Spain). Sediment Geol 219: 97-114.

PLA-PUEYO S, VISERAS C, CANDY I, SORIA JM, GARCÍA-GARCÍA F AND SCHREVE D. 2015. Climatic control on palaeohydrology and cyclical sediment distribution in the Plio-Quaternary deposits of the Guadix Basin (Betic Cordillera, Spain). Quat Int 389: 56-69.

RAO VB, CAVALCANTI IFA AND HADA K. 1996. Annual variation of rainfall over Brazil and water vapor characteristics over South America. J Geophys Res 101: 26539-26551.

RIBEIRO LMAL, SAWAKUCHI AO, WANG H, SALLUN FILHO W AND NOGUEIRA L. 2015. OSL dating of Brazilian fluvial carbonates (tufas) using detrital quartz grains. Quat Int 362: 146-156.

SALLUN FILHO W AND KARMANN I. 2007. Geomorphological map of the Serra da Bodoquena karst, west-central Brazil. J Maps 3(1): 282-295.

SALLUN FILHO W, KARMANN I, BOGGIANI PC, PETRI S, CRISTALLI PS AND UTIDA G. 2009a. A deposição de tufas quaternárias no estado de Mato Grosso do Sul: proposta de definição da formação Serra da Bodoquena. Geol USP Série Científica 9: 47-60.

SALLUN FILHO W, KARMANN I, SALLUN AEM AND SUGUIO K. 2009b. Quaternary tufa in the Serra da Bodoquena Karst, West-Central Brazil: Evidence of wet period. IOP Conf Ser Earth Environ Sci 6: 072055.

SHEN CC, LAWRENCE RE, CHENG H, DORALE JA, THOMAS RB, BRADLEY SM, WEINSTEIN SE AND EDMONDS HN. 2002. Uranium and thorium isotopic and concentration measurements by magnetic sector inductively coupled plasma mass spectrometry. Chem Geol 185: 165-178.

SINHA R, TANDON SK, SANYAL P, GIBLING MR, STUBEN D, BERNER Z AND GHAZANFARI P. 2006. Calcretes from a Late Quaternary interfluve in the Ganga Plains, India: Carbonate types and isotopic systems in a monsoonal setting. Palaeogeogr Palaeoclimatol Palaeoecol 242: 214-239.

SOTO G, DONOSO MC, GABRIELS D, SANTIBAÑEZ F, VERBIST K, APARICIO J, VELASCO I, LOBO D, PIZARRO R AND MAY Z. 2006. Zonation of Water Regimes in Latin America and the Caribbean from a climatic point of view. UNESCO, La Serena, Chile. http:// www.unesco.org.uy/phi/biblioteca/items/show/10 Acesso em: 25 de junho de 2016.

STRIKIS NM, CRUZ FW, CHENG H, KARMANN I, EDWARDS RL, VUILLE M, WANG X, DE PAULA MS,
NOVELLO VF AND AULER AS. 2011. Abrupt variations in South American monsoon rainfall during the Holocene based on a speleothem record from central-eastern Brazil. Geology 39: 1075-1078.

TEIXEIRA W, TASSINARI C, CORDANI U AND KAWASHITA K. 1989. A review of the geochronology of the Amazonian Craton: Tectonic implications. Precambrian Res 42: 213-227.

TURCQ B, SUGUIO K, SOUBIÉS F, SERVANT M AND PRESSINOTTI MN. 1987. Alguns terraços fluviais do Sudoeste e do Centro-Oeste brasileiro por radio-carbono: possíveis significados paleoclimáticos. In: I Congresso da Associação Brasileira de Estudos do Quaternário. Porto Alegre (RS), p. 379-392.

USSAMI N, SHIRAIWA S AND DOMINGUEZ JML. 1999. Basement reactivation in a sub-Andean foreland flexural bulge: The Pantanal wetland, SW Brazil. Tectonics 18: 25-39.

VALENTE CR ET AL. 2004. Folha SD.21-Cuiabá. In: Schobbenhaus C, Gonçalves JH, Santos JOS, Abram MB, Leão Neto R, Matos GMM, Vidotti RM, Ramos MAB and Jesus JDA (Eds), Carta Geológica do Brasil ao Milionésimo, Sistema de Informações Geográfica. CPRM, Brasília. http://rigeo.cprm.gov.br/xmlui/handle/ doc/16572 Acesso em: 2 de junho de 2016.

VERA C ET AL. 2006. Toward a unified view of the American monsoon systems. J Clim 19: 4977-5000.

VUILLE M, BURNS SJ, TAYLOR BL, CRUZ FW, BIRD BW, ABBOTT MB, KANNER LC, CHENG H AND NOVELLO VF. 2012. A review of the South American monsoon history as recorded in stable isotopic proxies over the past two millennia. Clim Past 8: 1309-1321.

WALKER MJC, BERKELHAMMER M, BJÖRCK S, CWYNAR LC, FISHER DA, LONG AJ, LOWE JJ, NEWNHAM RM, RASMUSSEN SO AND WEISS H. 2012. Formal subdivision of the Holocene Series/Epoch: a Discussion Paper by a Working Group of INTIMATE (Integration of ice-core, marine and terrestrial records) and the Subcommission on Quaternary Stratigraphy (International Commission on Stratigraphy). J Quaternary Sci 27: 649-659.

WANG X, AULER AS, EDWARDS RL, CHENG H, CRISTALLI PS, SMART PL, RICHARDS DA AND SHEN CC. 2004. Wet periods in northeastern Brazil over the past $210 \mathrm{kyr}$ linked to distant climate anomalies. Nature 432: 740-743.

WHITNEY BS, MAYLE FE, PUNYASENA SW, FITZPATRICK KA, BURN MJ, GUILLEN R, CHAVEZ E, MANN D, PENNINGTON RT AND METCALFE SE. 2011. A $45 \mathrm{kyr}$ palaeoclimate record from the lowland interior of tropical South America. Palaeogeogr Palaeoclimatol Palaeoecol 307: 177-192. 
WRIGHT VP. 1992. A revised classification of limestones. Sediment Geol 76: 177-185.

WRIGHT VP, ALONSO-ZARZA AM, SANZ ME AND CALVO JP. 1997. Diagenesis of Late Miocene micritic lacustrine carbonates, Madrid Basin, Spain. Sediment Geol 114: 81-95.
WRIGHT VP AND TUCKER ME. 1991. Calcretes. Blackwell Publishing, Oxford, England.

ZHANG DD, ZHANG Y, ZHU A AND CHENG X. 2001.

Physical Mechanisms of River Waterfall Tufa (Travertine)

Formation. J Sediment Res 71: 205-216. 